\title{
The Bifocality of Dance in Shakespeare's Twelfth Night: An Analysis of Shakespearean Dance Adaptations
}

\author{
Kimberly M. Glassman
}

PhD student, Queen Mary University London, United Kingdom

Mail Id: kim.m.glassman@gmail.com | ORCID ID: 0000-0002-6990-8856

\begin{abstract}
Drawing on Lynsey McCulloch's notion of Shakespeare in dance and Shakespeare as dance, this paper explores the bifocality of Shakespeare and dance in Twelfth Night. In Illyria, a realm of fantasy, dance is a measure of dismantling, whilst maintaining, a cosmic order. Taking a psychohistorical approach, I draw on Alan Brissenden's 1981 Shakespeare and the Dance, which delves into the moral implications of dancing in Shakespeare's time. Moving from print to performance and screen, I venture into an analysis of Boris Eifman's 1986 ballet-film adaptation of Twelfth Night. By adding layers of fiction as both a ballet and film, Eifman's work enhances Shakespeare's utopian/dystopian realm of Illyria and taps into the aforementioned psychological undertones. Eifman's literal use of dance transforms the play into a psychological sensorial experience and delves deeper into the implications of dance hinted at in the text. Most interesting, by adapting words to movement, Eifman uses dance to both conceal and reveal elements of the story. By engaging in an analysis of Shakespeare's Twelfth Night text and subsequent dance adaptations one may witness the bifocality of Shakespeare and dance, and the complexity it brings to our understanding of Shakespeare then and now.
\end{abstract}

Keywords: Dance Adaptation, Twelfth Night, Boris Eifman, Bifocality of Shakespeare and Dance, Experimental Russian Ballet

\section{Introduction:}

Lynsey McCulloch states, "[t]he dance that appears within literature is as absorbing as that which reimagines it" (McCulloch, 69). In her seminal text "Shakespeare and Dance," McCulloch theorizes that a bilateral relationship exists between dance in Shakespeare and Shakespeare as dance. An analysis of this relationship invites an exploration of the communicative range dance offers both text and performance. Thus to fully understand, appreciate and experience a Shakespearean dance adaptation such as Boris Eifman's 1986 ballet-movie Twelfth Night, we must first dive into Shakespeare's text and witness first-hand the full comedic, tragic, psychological and metaphorical 
meanings behind dance in Shakespeare. Only then may we address Shakespeare as dance by analyzing choreography as a mode of communication in Shakespeare's play and turning to the dance in Eifman's ballet-movie, which is here seen as a means to further explore and experiment with topics in Twelfth Night, specifically passion, death, and the faculties of the mind.

The play, for all intents and purposes, is a comedic love story that begins with confusion and ends in marriage. A shipwreck leaves Viola stranded on the island of Illyria where - as a precaution after assuming her twin brother, Sebastian, has died at sea - she takes on the guise of a man named Cesario to work for the Duke Orsino. Viola falls in love with the Duke, who is in love with the Countess Olivia, who in turn falls in love with Viola's male persona, Cesario. The play comes to an end when Sebastian is revealed to be alive and Viola reveals herself to be a woman, an action which instigates the couples finally being able to marry: Duke Orsino to Viola and Sebastian to Olivia. Throughout the play, identities are masked by gender and folly. The characters' interactions and dialogues often take on a choreographic semblance, referencing at times dances popular in Shakespeare's day. The following section will address the communicative uses and metaphorical meanings of dance in Shakespeare's Twelfth Night, specifically through Sir Toby's use of dance metaphors to communicate with Sir Andrew and Feste and how, in doing so, Sir Toby's character (perhaps unknowingly) unravels the ending of the plot.

\section{Dance in Shakespeare's Twelfth Night}

Through the mouthpiece of Olivia's uncle, Sir Toby Belch, Shakespeare illustrates the manner in which dance is used as a vehicle for communication in Twelfth Night. In Act 1, Scene 3, Sir Toby entreats his companion Sir Andrew Aguecheek to stay and woo his niece. Sir Andrew agrees to prolong his visit by one month because he "delight[s] in masques and revels" (1.3.95.). By comparing the pursuit of Olivia to courtly entertainment (and dancing), Shakespeare sets the tone for the other love pursuits in the play. The following evidence supports this view whilst demonstrating a continuous metaphor of courting as choreographed dance in Shakespeare's text.

Sir Toby begins, in the very next line, to mock Sir Andrew by asking him, "Art thou good at these kickshawses, knight?" (1.3.97). Kickshawes were, according to Skiles Howard, a dance used to establish the "measurement of a man" depending on the jump's height and amplitude (Howard, 334). This is reinforced when Sir Toby yells, "Ha, higher!" at the end of the scene (1.3.118-119). Sir Toby proceeds to ask Sir Andrew directly if he can dance a "galliard," which is a five-step lively dance in double time (1.3.101). Though out-dated by the time Shakespeare wrote the play, the galliard was a well respected dance known for exemplifying a man's virtue through his "agility, precision, ... rapidity of footwork, and muscular strength" (Çikigil, 267). Sir Andrew assures his friend that he can dance and thus, following the metaphor, woo his niece stating, "Faith, I can cut a caper" - a caper being the leap before the fifth step in a galliard (1.3.102). However, those who knew of the galliard dance in Shakespeare's time would have understood that the reference indicates not that Sir Andrew can actively pursue Olivia, but that while he is busy "cutting-capers" - or showing off, as is the meaning in the dance - "the lady [Olivia] must promenade around him in admiration" 
(Çikigil, 267). Thus when Sir Toby metaphorically asks if he can dance, Sir Andrew fails to register the metaphor and misunderstands the conversation. In doing so, Sir Andrew undermines his answer and proves himself unfit to woo when failing to respond in the "masques" (1.3.95) he loves so well.

According to Shakespeare scholar Nekla Çikigil, "[w]hether in concord or discord, characters can 'become' the dancing pairs of Renaissance dances," such as "the famous corantos, [and] galliards" (Çikigil, 267). It is thus notable that the galliard was Shakespeare's dance of choice in this dialogue because according to Peggy Dixon, the galliard is first and foremost "a dialogue in which two dancers (characters) dance (talk) to each other," and not with each other (Çikigil, 267). When Sir Andrew states, "I think I have the back-trick simply as strong as any man in Illyria" (1.3.104-105), he is really saying he is good at taking the back step of the galliard - in other words - at disengaging from his partner. The idea that Sir Andrew will never successfully obtain Olivia in his dance/pursuit culminates in Sir Toby's last long dialogue of the scene where he states:

"Why dost thou not go to church in a galliard and come home in a coranto? My very walk should be a jig. I would not so much as make water but in a sink-a-pace. What dost thou mean? Is it a world to hide virtues in? I did think, by the excellent constitution of thy leg, it was formed under the star of a galliard" (1.3.108-113).

In the first line Sir Toby mocks Sir Andrew's ability to woo a woman by asking him why he does not go to church dancing a duet (the galliard) and come home dancing the coranto, which is a dance wherein "three gentlemen choose three ladies and try to attract their attention with amorous gestures. The ladies first turn away and ignore the approaches until finally they all dance merry together" (Çikigil, 267). In other words, if he is so good at dancing/courting, then let's see it! Nearing the end Sir Toby says that he thought, "by the excellent constitution of thy leg," (metaphorically his ability to dance/court) "it was formed under the star of a galliard," (referencing his natural disposition). Sir Andrew agrees with his friend that his legs are suitable for dancing, falling out of the pre-established metaphorical conversation, and proving ultimately that he cannot keep within the masked dialogue. However the mentioning of the coranto also foreshadows the play's denouement. At the end of the play, three marriages take place: Olivia marries Sebastian, Viola marries Duke Orsino (strictly speaking, this marriage has yet to take place), and Sir Toby marries Maria. At the beginning of the plot, each pair is ignored and remains unnoticed by their inevitable 'partner' until the very end of the comedy when, true to form, the play wraps up in a happy ending where everyone is married, or in other words, everyone completes the coranto dance together.

Sir Toby seems to direct his second question towards the audience rather than to Sir Andrew when he inquires, "[i]s it a world to hide virtues in?" (1.3.111). The "it" he refers to can either be understood as an allusion to the dancing/wooing he spoke about previously, or as a reference to the "masques and revels" Sir Andrew first claimed he delighted in. Either way, one can understand the "world" as the play, and "virtues" as one's true self. Two layers of meaning thus begin to form in keeping with Sir Toby's metaphorical dialogue: first, that the true intention and identity of the 
character is hidden amongst the masqueraded love-encounters of the play, and second, more broadly speaking, that the truth is hidden in a world of dance. In doing so, one may understand the individual as a microcosmic reflection of the Shakespearean world of comedy wherein the character may only take off the mask when the coranto comes to an end, when the comedy is resolved, when everyone marries and his or her 'virtues' (or identities) no longer remain hidden. The microcosmic is here defined as "the single state of man" and "the state of man" as "a little kingdom" (Bundy, 533).

\section{Shakespeare as dance in Eifman's ballet-movie of Twelfth Night}

While the individual is seen as a microcosmic reflection of the Shakespearean world in this analysis, Russian choreographer Boris Eifman's ballet-movie can be understood as a microcosmic reflection of the impassioned state of mind. Whereas dance was used metaphorically as a mode of communication between characters in the play, it is used literally in the ballet-movie as a means to express a psychological state (passion/reason) of a person (the filmed audience). Drawing on contemporary and Renaissance psychology, we may witness how dance reveals and heightens nuances of the faculties of the mind in the play and how these themes have been adapted to dance.

Eifman is well known for his numerous novel-inspired ballets. His intention "to express the fiery passions of ballets' characters," has been acknowledged by many as one of the most distinguishing features of his work and is particularly evident in his adaptation of Twelfth Night ("The Company"). Eifman's literal use of dance transforms the play into a psychological and sensorial experience that delves deeper into the implications of dance hinted at in Shakespeare's text.

In doing so, Eifman's Twelfth Night magnifies a selection of nuances in Shakespeare's play. Filmed as a ballet-movie, Eifman draws on Shakespeare's Illyria as a realm of fantasy. The ballet begins with imagery of a boat at sea. Those familiar with Twelfth Night will associate this image with the shipwreck that separates Viola and Sebastian at the beginning of the play. Playing with the viewer's assumptions, however, Eifman tricks his audience and instead has the twins disembark from the ship to enter a cinema together, taking their seats amongst a filmed audience. It is only once Feste, Countess Olivia's court jester, has introduced the ballet and its dancers that Viola and Sebastian become attracted to the doubly fictional world being played out in front of them. They are drawn, as if by an extraordinary force, towards the ballet when Duke Orsino attempts to woo Olivia. Despite Feste's delicate attempt to stop them from joining in the choreography, the twins present themselves on stage, much to the confusion and bemusement of the audience(s).

Eifman explains that he "strive[s] to express not the text, not the plot, but that which exists between the lines, that which moved and inspired [him] while reading" (Barnett and Skelton, 25). While it is possible to complete this analysis of dance bifocality by discussing how the dances mentioned and used in Shakespeare's work are then directly adapted/used in Eifman's ballet - as for example in the aforementioned exchange between Sir Toby and Sir Andrew (one of the opening scenes of the ballet), during which one of the first dance combinations given to Sir Andrew is a series of high jumps, not unlike the kickshawses previously mentioned. However, this analysis will focus more on Eifman's adaptation of the play as an experimental ballet pushing the boundaries of text 
exploration. Robin Wharton said it best when she stated, "[t]he source text is not reproduced so much as manipulated [using] ballet's kinaesthetic vocabulary. It becomes simply another tool for making meaning on stage, and the meaning that emerges, although influenced by the source text, is in no way limited by or grounded within it" (Wharton, 20). Thus though, as scholar Clive Barnes asserts, "[t]he balletomane also imports his or her own understanding of the play as a cultural artefact embedded in a critical apparatus designed to tease out the psychological and social motivations of its characters" (Barnes, 142), it is more appropriate to direct our attention not to what is recognizable in the ballet adaptation, but to that which is foreign and new to the audience.

In Eifman's ballet, the development of the plot takes on a symbolic rather than literal quality. The choreography is composed of large groups dancing in provocative, comedic and lewd manners with thrusting, accidental collapsing, layering of dancers, and over-exaggerated movements. While it is possible to follow the play's plot as the ballet-movie unfolds, Eifman uses metatheatrics to tell two stories at once and expand the themes beyond simply the ballet or the text exclusively. The division of realities between the ballet stage performance and the filmed audience performance creates an illusion of phantasmagorical realism. With this term I refer to the combination of a bizarre or fantastic assemblage of choreography matched with an undeniable concern or affirmation of fact of reality. The viewer identifies with the acted audience (themselves being an audience), but they are reminded through the evident layering of fiction that what they are really looking at is a deceptive world of imagination. The question remains, what purpose has this fantasy-reality dualism served? In other words, why would Eifman want us to both believably identify with the main characters, and be clearly and undoubtedly aware of the fantasy at play?

The answer, I believe, lies with a key theme Shakespeare introduces in Twelfth Night: Passion. Knowing that Eifman is "very fond of psychoanalysis (Freud and Jung)" and that he is interested "in exploring extremes of emotion through movement" (Reiter), we may understand his ballet as a cacophony of sounds, expressions and choreographies that evoke and map out a kinaesthetic interpretation of passion or of the impassioned state of mind. Freudian psychoanalysis centers a great deal on passion as it is thought to be one of the sources of our unconscious drives (Karlsson, 112-113). However, passion is not a fixed state, it "is always directed towards something" (Campbell, 1). According to Jan Campbell, "[w]e could call that something an object, but before the object exists, or after it is destroyed or lost, passion is in search of a form in which it can be dressed and carried" (Campbell, 1). Eifman's ballet exemplifies passion seeking its form. When Viola and Sebastian get up from their seats to enter the ballet, they are drawn by their passion "to a place beyond the ego and all reason, to the madness..." (Campbell, 2). The filmed audience adds a layer to the ballet, that of a fictional film, which holds a place in this analysis in its own right.

Austrian author, dramatist and contemporary of Freud, Arthur Schnitzler "realized that the theatre audience, like the psychiatrist, draws its conclusions directly and solely from human behaviour" (Kandel, 82). The impassioned state of mind (representing unconsciousness) can be understood as expressed through performance of bodily action and received by the passive seated theatre audience (representing consciousness). The ballet can here be understood as an exploration of a state of mind, or rather a state of emotion. For passion undoes the very fabric that holds together 
our reality, or what Freud would term the ego. Passion "expos[es] the ultimate separation of the individual from shared experience" (Viola and Sebastian leaving the audience), but in marking "a break from social existence, it is also the nature of passions, their immediacy and transparency, which makes them shareable" (the acted-audience is privy to witness the passion on stage) (Campbell, 157). For example, when Malvolio - who in this reading embodies the passion that does not find/attain its form - leaves the ballet and enters the audience he is reaffirming the paradoxical qualities of passion: that it separates you from the group whilst bringing you together. Simply put, psychological drives, such as passion, come from the unconscious - it is the forms that differ.

Eifman's choreography visually represents and emphasizes the passion paradox through his numerous group scenes. Almost every second scene is comprised of two elements: a pas de deux or pas de trois between those who are courting, or those who are being courted (representing passion following its form), and a chorus who echo the emotions present on stage through their own choreography (representing passion as a shared experience). Thus, in surpassing the ego, or state of reality/reason, Eifman's dancers express the emergence, pursuit, and infection of passion. Moreover, Shakespeare often equates passion or lust to contagion - another theme that I believe is amplified in Eifman's adaptation.

\section{Contagion, passion and death through dance}

Dance, song, and by extension, love are each often equated to death and the plague in Shakespeare's Twelfth Night. In Act 1, scene 5, falling in love is likened to catching the plague as seen when Olivia exclaims, "[u]nless the master were the man. How now? Even so quickly may one catch the plague?"(1.5.263-264). As we have already established, in Shakespeare's play, love and wooing are likened to music and dancing. Thus, in establishing a decisive link between love and death, Shakespeare demonstrates the macabre undertones of comedic unrequited love, encapsulated in Feste's initial commentary on death being the necessary catalyst that leads everyone to their happy endings: "Many a good hanging [le petit mort] prevents a bad marriage" (1.5.17-18).

In Act 2, scene 3, Feste is described as having "contagious breath" when singing a love song, insinuating that he has an infectious voice (2.3.48). Here again Sir Toby takes the opportunity to mock Sir Andrew by confusing him when stating, "[t]o hear by the nose, it is dulcet in contagion" (2.3.50). Toby herein references the plague-time practice of breathing through perfumed handkerchiefs. Moreover, a death-sex mix is soon after introduced when Sir Toby sings, "But I will never die," and Feste responds singing, "Sir Toby, there you lie" (2.3.94-95). Shakespeare scholars posit that Shakespeare, through Toby, might be parodying a melodramatic death, but he could also be equating the experience of death to that of sexual pleasure.

Eifman incorporates his own allusions to the death-sex mix into his ballet-film. Death can be found in various points of Eifman's work: A group of nuns surround Olivia, who is dressed all in black until she is married, and Duke Orsino is escorted offstage after being rejected by Olivia, hoisted up as if he were being carried in a coffin - to name but a few particular instances. However, instead of alluding to the plague, I believe Eifman is drawing inspiration from Freud's dichotomous drive 
theory where sex and passion partake in both the drive towards life, Eros, and the drive towards death, Thanatos. Passion or sex is used for pro-creation in the drive towards life, whereas sex is used primarily for pleasure in the drive towards death (Karlsson, 112-113). There is a sharp juxtaposition between the almost crass and over-erotic choreographic combinations that make up the majority of the ballet and the very pristine, white, traditional ending where the couples pair off and marry.

The back and forth movement of the scenes, choreographies, and emotions amplify not the division but the eternal struggle between these two drives theorized by Freud. Viola and Sebastian take on the role of voyeur, looking in on the object of their passions. While not in their 'true' identities they cannot use their passion as a drive towards life because the match cannot, much as in Shakespeare's play, be sanctioned in this universe. However, once the identities are re-established, and, metaphorically speaking, our coranto has come to an end - passion can be used to pursue the drive for life in the purity of marriage and the engenderment it implies.

Eifman thus kinaesthetically expands on Shakespeare's themes of dance, passion, and death in Twelfth Night. Shakespeare could not have foreseen artists creating adaptations of his work that also draw from Freudian psychoanalysis - it would take a retroactive, ahistorical analysis to join Freud and Shakespeare on the same page. However, Shakespeare did allude to the psychology of his day. For example, Sir Toby inquires, "Shall we rouse the night owl in a catch that will draw three souls out of one weaver?" (2.3.51-52). The "three souls" is an allusion to the three faculties of the soul reason, feeling and passion. According to Murray W. Bundy, there was a "Renaissance distinction between the faculties of knowledge and those of action" (Bundy, 520). In this sense, reason and position were thought to be faculties of the mind and knowledge, and appetite and affection were believed to be faculties of the body and action (Bundy, 520). Through a Renaissance understanding of psychology, Eifman's work can be seen as an exploration of the appetite of affection superseding the faculties of the mind, Freud's 'ego'. However, psychology has changed quite a bit since the 1600s, and therefore a psychohistorical analysis of Twelfth Night does not, in my view, do Eifman's adaptation justice.

\section{Conclusion:}

In conclusion, Eifman's literal use of dance transforms the play into a psychological sensorial experience that delves deeper into the implications of dance hinted at in the text. Eifman's adaptation can be experienced as a kinaesthetic interpretation of passion and a deliberate exposure of the macabre undertones ofcomedic unrequited love in Shakespeare's text. In sum, by adapting words to movement, Eifman uses the bilateral relationship that exists between dance in Shakespeare and Shakespeare as dance as a means to further explore topics in Twelfth Night, specifically that of passion, death and the faculties of the mind.

Eifman, through the medium of dance and film, has brought Shakespeare into the 20th and 21st century. He has kept his work alive not only as cultural artefact, but as a means of communicating, 
expressing, and exploring themes that have been subject to an evolution over time - and yet, have remained perpetually and globally relevant throughout these past 400 years. Eifman's dance adaptation invites us to explore the bifocality of Shakespeare and dance, its implications and the complicated richness it brings to our understanding of Shakespeare then and now.

\section{References}

"The Company." Eifmanballet.ru. N.p., 2017. Web. 6 Mar. 2021. <http://www.eifmanballet.ru/en/about/theatre>.

Barnes, Clive. "The Bard Dances. - Free Online Library." Thefreelibrary.com. N.p., 1997. Web. 16 June 2021. <https://www.thefreelibrary.com/The+bard+dances.-a019156669>.

Barnett, Dennis and Skelton, Arthur. Theatre and Performance in Eastern Europe: The Changing Scenes. United States: Scarecrow Press, 2008. Print.

Barnett, Dennis, et al. Theatre and Performance in Eastern Europe. Netherlands: Amsterdam University Press, 2008. Print.

Brissenden, Alan. Shakespeare and the Dance. London, Humanities Press, 2021.

Brissenden, Alan. Shakespeare and the Dance. London: The MacMillan Press, 1981.

Bundy, Murray W. "Shakespeare and Elizabethan Psychology," The Journal of English and Germanic Philology 23.4 (Oct., 1924): pp 516-549.

Campbell, Jan. Freudian Passions: Psychoanalysis, Form, and Literature. London: Karnac Books, 2013.

Çikigil, Nekla. "Renaissance Dance Patterns in Shakespeare's Italian Plays: An analysis of dialogues," Studies in Theatre and Performance 26.3. 2006.

Eifman, Boris. Twelfth Night. 1986. Web. 16 May 2021. <https://www.youtube.com/watch?v=GABbgR4KFFA>. Hopkins, Lisa. The Shakespearean Marriage: Merry Wives and Heavy Husbands. London: McMillan Press, 1998. Print.

Howard, Skiles. "Hands, Feet, and Bottoms: Decentering the Cosmic Dance in A Midsummer Night's Dream."Shakespeare Quarterly 44, no. 3 (1993): pp 325-42. doi:10.2307/2871422.

Kandel, Eric R. The Age of Insight: The Quest to Understand the Unconscious in Art, Mind, and Brain, from Vienna 1900 to the Present. New York: Random House, 2012. Print.

Karlsson, Gunnar, "Life Drives Versus Death Drives," Psychoanalysis in a New Light. UK: Cambridge University Press. 2010. Print.

McCulloch, Lynsey. “Shakespeare and Dance," Literature Compass 13/2 (2016): 69-78, 10.1111/lic3.12313.

Oatley, Keith. "Simulation of Substance and Shadow: Inner Emotions and Outer Behavior in Shakespeare's Psychology of Character," College Literature, Vol. 33, No. 1, Cognitive Shakespeare: Criticism and Theory in the Age of Neuroscience (Winter, 2006): pp 15-33.

Reiter, Susan. "Boris Eifman on creating 'a new type of theater' in ballet." Los Angeles Times (May 29, 2015). http://www.latimes.com/entertainment/arts/la-ca-cm-eifman-ballet-20150531- story.html

Shakespeare, William. Twelfth Night, ed. R.S. White, Houndmills: Macmillan, 1996. Print.

The Shakespeare Dance Project. "Dancing in Twelfth Night: Courtly versus Carnal Entertainments," The Shakespeare Dance Project, excerpted from Winerock, Emily F. "The Bard's Galliard: A Practical Guide to Shakespearean Dance" (Princeton, 1999). <https://shakespeareandance.com/articles/dancing-in-twelfthnight-courtly-versus-carnal- entertainments/>

Wharton, Robin, "There are no Mothers-In-Law in Ballet": "Doing" Shakespeare in Dance," Shakespeare Bulletin 23.3, Fall, 2005. 
Winerock, Emil F. "Shakespearean Dance Resource Guide." Winerock.com. 10 March, 2015. <http://winerock.altervista.org/shakespeareandance/>

Kimberly Glassman is a PhD student at Queen Mary University London. Her research interests include the history of art, science, floricultural history, and adaptation studies. Kim is a research assistant for Dr Munroe on her new book project, Mothers of Science: Women, Nature, and Writing in Early Modern English Literature. 